\title{
Shimia marina gen. nov., sp. nov., a novel bacterium of the Roseobacter clade isolated from biofilm in a coastal fish farm
}

\author{
Dong H. Choit and Byung C. Cho
}

Correspondence

Byung C. Cho

bccho@snu.ac.kr
School of Earth and Environmental Sciences and Research Institute of Oceanography, Seoul National University, 56-1 Shillim-dong, Kwanak-gu, Seoul 151-742, Republic of Korea
A rod-shaped marine bacterium, CL-TA03 ${ }^{\top}$, isolated from a biofilm in a coastal fish farm in Tongyeong, Korea, was characterized for physiological and biochemical features, fatty acid profile and phylogenetic position based on 16S rRNA gene sequences. Analysis of the 16S rRNA gene sequence revealed a clear affiliation with the family Rhodobacteraceae. Phylogenetic analysis of the 16S rRNA gene sequence showed that the closest relatives of CL-TA03 ${ }^{\top}$ were Thalassobius gelatinovorus and Thalassobius mediterraneus (95.6\% similarity). The sequence similarities between CL-TA03 ${ }^{\top}$ and other type species of the Roseobacter lineage ranged from 92.4 to $95 \cdot 4 \%$. Strain CL-TA03 ${ }^{\top}$ is motile and grows on marine agar as colourless or beige colonies. The strain is able to grow optimally in the range of 3-5\% sea salts. It grows within a temperature range of $15-35^{\circ} \mathrm{C}$ and at $\mathrm{pH} 6-10$. The fatty acids are dominated by $18: 1 \omega 7 c(64 \cdot 1 \%)$ and 11-methyl $18: 1 \omega 7 c(10 \cdot 6 \%)$. The DNA G +C content is $57 \cdot 2 \mathrm{~mol} \%$. According to physiological data, fatty acid composition and phylogenetic analysis of the 16S rRNA gene sequence, $\mathrm{CL}-\mathrm{TAO} 3^{\top}$ is considered to represent a new genus in the family Rhodobacteraceae and the name Shimia marina gen. nov., sp. nov. is proposed. The type strain of Shimia marina is CL-TA03 ${ }^{\top}\left(=\right.$ KCCM $42117^{\top}=$ JCM $\left.13038^{\top}\right)$.
Strains in the Roseobacter clade, classified within the family Rhodobacteraceae, have been isolated mainly from various marine environments (seawater, sediment, hypersaline microbial mats and coastal biofilms) and from marine algae, invertebrates and vertebrates, and the Roseobacter clade is known to be one of the most abundant groups in marine environments (Giovannoni \& Rappé, 2000; Selje et al., 2004; Buchan et al., 2005). The strains show diverse physiological and morphological features (e.g. phototrophy, aerobic sulfite oxidation, organic sulfur compound degradation, methylotrophy, gas vacuoles, poly- $\beta$-hydroxybutyrate granules, rosette formation) (Arahal et al., 2005; Buchan et al., 2005). Furthermore, phylogenetic analyses of marine Roseobacter sequences have shown that for two-thirds (68\%) of the Roseobacter diversity identified so far, it is not yet possible to access relevant physiological information through studies of cultured organisms (Buchan et al., 2005). In early stages of biofilm establishment, clones affiliated with the Roseobacter clade accounted for $85 \%$ of the total sequenced clones, suggesting that organisms belonging to

†Present address: Marine Environmental Research Department, Korea Ocean Research and Development Institute (KORDI), Ansan 426-744, Republic of Korea.

The GenBank/EMBL/DDBJ accession number for the 16S rRNA gene sequence of strain CL-TA03 ${ }^{\top}$ is AY962292. the Roseobacter clade are ubiquitous and rapid colonizers of surfaces in coastal environments (Dang \& Lovell, 2000).

In this study, a strain affiliated with the Rhodobacteraceae, $\mathrm{CL} \mathrm{TA} 03^{\mathrm{T}}$, was isolated in October 2002 from a biofilm formed on an acrylic slide submerged for 1 month in surface water on a coastal fish farm in Tongyeong, Korea. The scraped biofilm was suspended in seawater that had been passed through a $0.2 \mu \mathrm{m}$ filter and autoclaved. The suspension was spread on a marine agar 2216 (MA; Difco) plate and incubated at $25^{\circ} \mathrm{C}$ for 1 week. Strain CL-TA03 ${ }^{\mathrm{T}}$ was isolated and subsequently purified four times on MA at $30{ }^{\circ} \mathrm{C}$. The strain was maintained both on MA at $4{ }^{\circ} \mathrm{C}$ and in marine broth 2216 (MB; Difco), supplemented with $30 \%$ (v/v) glycerol, at $-80^{\circ} \mathrm{C}$.

The 16S rRNA gene was amplified from a single colony by PCR with Taq DNA polymerase (Bioneer) using primers 27F and 1492R (Lane, 1991). The PCR product was purified using the AccuPrep PCR Purification kit (Bioneer) and cloned using the pCR2.1 TOPO TA Cloning kit (Invitrogen). Sequencing of the 16S rRNA gene was performed with an Applied Biosystems automatic sequencer (ABI 3730xl) at Macrogen Corp., Seoul, Korea. An almost complete 16S rRNA gene sequence of strain CL-TA03 ${ }^{\mathrm{T}}$ (1382 bp) was obtained. The sequence of strain CL-TA03 ${ }^{\mathrm{T}}$ was compared with 16S rRNA gene sequences available in GenBank using 
BLASTN searches (Altschul et al., 1990). The sequence of strain CL-TA $03^{\mathrm{T}}$ was aligned manually with those of type strains of species belonging to genera phylogenetically related to CL-TA $03^{\mathrm{T}}$ and with type species of other genera in the Roseobacter clade within the family Rhodobacteraceae obtained from GenBank and from the Ribosomal Database Project (Cole et al., 2003) databases using known 16S rRNA secondary structure information. Phylogenetic trees were obtained by neighbour-joining (Saitou \& Nei, 1987) and maximum-parsimony (Fitch, 1971) methods. An evolutionary distance matrix for the neighbour-joining method was generated according to the model of Jukes \& Cantor (1969). The robustness of tree topologies was assessed by bootstrap analyses based on 1000 replications for neighbour-joining and maximum-parsimony methods. Alignment analysis was carried out using the jPHYDIT program (Jeon et al., 2005) and phylogenetic analyses were carried out using MEGA3 (Kumar et al., 2004). The $16 \mathrm{~S}$ rRNA gene sequence of CL-TA03 ${ }^{\mathrm{T}}$ showed $95 \cdot 6 \%$ sequence similarity to Thalassobius gelatinovorus IAM $12617^{\mathrm{T}}$ and Thalassobius mediterraneus XSM19 ${ }^{\mathrm{T}}$, $95 \cdot 4 \%$ to Ruegeria atlantica IAM $14463^{\mathrm{T}}, 95 \cdot 1 \%$ to Silicibacter lacuscaerulensis ITI- $1157^{\mathrm{T}}$ and $92 \cdot 4-94 \cdot 8 \%$ to other type species of the Roseobacter lineage. In the phylogenetic trees, however, strain CL-TA03 ${ }^{\mathrm{T}}$ did not form a robust clade with any species in the Roseobacter lineage (Fig. 1). The DNA G $+\mathrm{C}$ content was determined by HPLC analysis of deoxyribonucleosides as described by Mesbah et al. (1989) after DNA purification using the method of Marmur (1961) and was found to be $57 \cdot 2 \mathrm{~mol} \%$.

Morphological and physiological analyses were performed. Gram staining was performed as described by Smibert \& Krieg (1994). Cell morphology and motility were examined by phase-contrast microscopy and transmission electron microscopy (JEOL EX2) with cells grown for 1 day at $30^{\circ} \mathrm{C}$ in MB and on MA. Anaerobic growth was checked on MA using the GasPak anaerobic system (BBL). Cells were rods of $0.3-0.6 \mu \mathrm{m}$ wide and $0.8-3.6 \mu \mathrm{m}$ long in exponential growth phase (Fig. 2). Cells occasionally formed small chains but not star-shaped aggregates. Cells were motile by several monopolar flagella (Fig. 2 ). Poly- $\beta$-hydroxybutyrate granules were not identified by transmission electron microscopy and Nile blue A staining (Ostle \& Holt, 1982). Colonies on MA were circular, entire, convex, opaque and colourless or beige. After incubation for 1 week, colonies

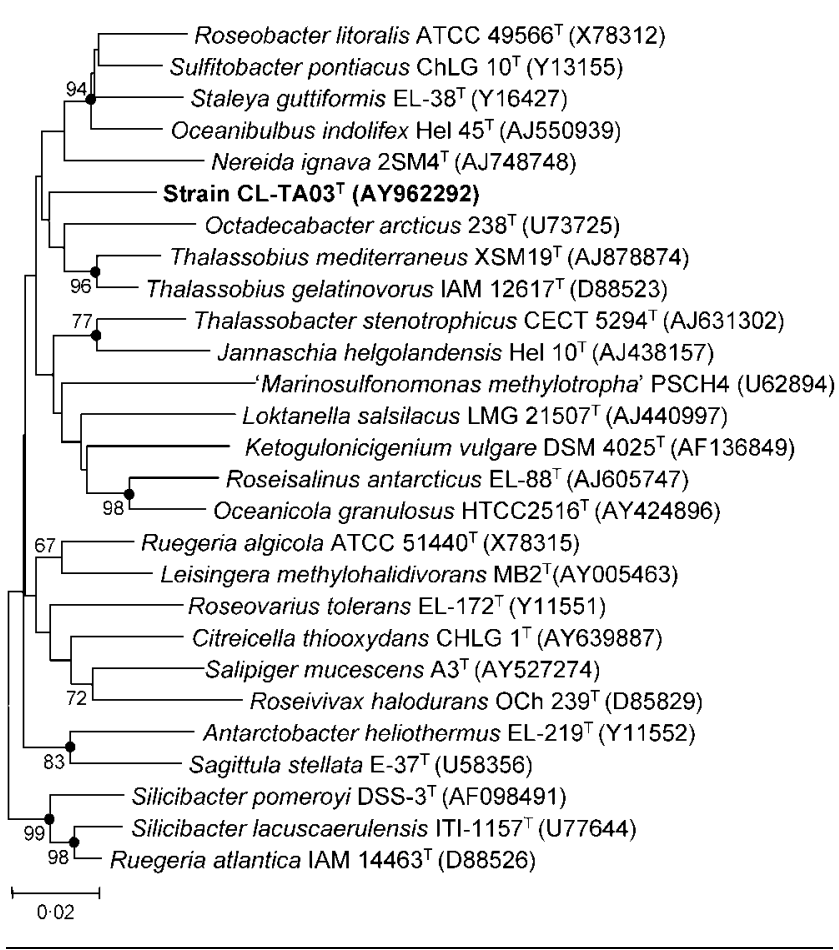

Fig. 1. Neighbour-joining tree based on 16S rRNA gene sequences showing the relationship between strain CL-TA03 ${ }^{\top}$ and other related species belonging to the Roseobacter clade of the family Rhodobacteraceae. Only bootstrap values above $60 \%$ are shown (1000 resamplings) at the branching points. Solid circles indicate that the corresponding nodes were also recovered in the maximum-parsimony tree. Idiomarina zobellii $\mathrm{KMM} 231^{\top}$ (GenBank accession no. AF052741) was used as an outgroup (not shown). Bar, 0.02 nucleotide substitutions per site.

were approximately $2 \mathrm{~mm}$ in diameter. Bacteriochlorophyll $a$ production was determined in $90 \%$ acetone extracts from cells cultured in the dark and examined using a spectrophotometer (Ultraspec 2000; Pharmacia Biotech). Bacteriochlorophyll $a$ was not detected in CL-TA03 ${ }^{\mathrm{T}}$.

The temperature range for growth was determined on the basis of colony formation on MA plates incubated at 5$45^{\circ} \mathrm{C}$. The $\mathrm{pH}$ range $(\mathrm{pH} 5-11)$ for growth was determined by changes in $\mathrm{OD}_{600}$ over time in $\mathrm{MB}$. The final $\mathrm{pH}$ was adjusted using $\mathrm{NaOH}$ and $\mathrm{HCl}$ solutions. Tolerance of
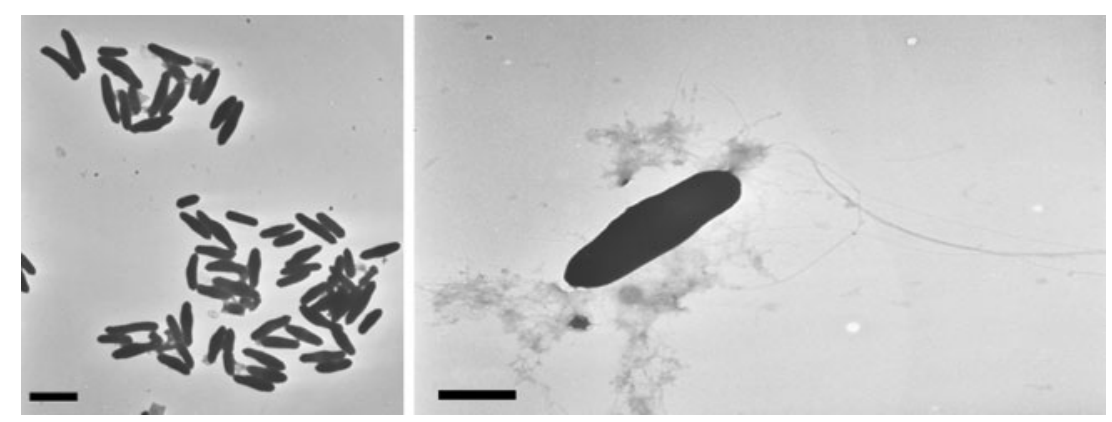

Fig. 2. Transmission electron micrographs of negatively stained cells of strain CL-TAO3 ${ }^{\top}$. Cells were grown at $30^{\circ} \mathrm{C}$ on MA for 1 day. Bars, $2 \mu \mathrm{m}$ (left) and $500 \mathrm{~nm}$ (right). 
Table 1. Selected characteristics that differentiate strain CL-TAO3 ${ }^{\top}$ from its closest phylogenetic relatives

Strains: 1, strain CL-TA03 ${ }^{\mathrm{T}} ; 2$, T. gelatinovorus IAM $12617^{\mathrm{T}} ; 3, T$. mediterraneus CECT $5383^{\mathrm{T}}$. Data for reference strains were taken from Arahal et al. (2005) unless indicated otherwise. +, Positive; - , negative; $\mathrm{W}$, weakly positive; ND, not detected or less than $1 \%$; ECL, equivalent chain length. All strains are Gram-negative, strictly aerobic and oxidase- and catalase-positive.

\begin{tabular}{|c|c|c|c|}
\hline Characteristic & 1 & 2 & 3 \\
\hline Motility & + & $+^{*}$ & - \\
\hline Poly- $\beta$-hydroxybutyrate accumulation & - & + & + \\
\hline Rosette formation & - & $+\dagger$ & - \\
\hline Temperature range for growth $\left({ }^{\circ} \mathrm{C}\right)$ & $15-35$ & $4-40$ & $13-37$ \\
\hline Growth on $1 \%$ sea salts & - & + & - \\
\hline DNA G + C content $(\mathrm{mol} \%)$ & $57 \cdot 2$ & 59 & 57 \\
\hline \multicolumn{4}{|l|}{ Enzyme activities } \\
\hline Amylase & W & $-\dagger$ & - \\
\hline Gelatinase & + & $+\dagger$ & - \\
\hline Nitrate reductase & + & $+\dagger$ & - \\
\hline \multicolumn{4}{|l|}{ API ZYM tests } \\
\hline Alkaline phosphatase & + & + & - \\
\hline Esterase lipase (C8) & $\mathrm{w}$ & + & + \\
\hline Valine arylamidase & - & + & - \\
\hline Acid phosphatase & $\mathrm{w}$ & + & - \\
\hline$\beta$-Galactosidase & - & + & - \\
\hline$\alpha$-Glucosidase & - & + & - \\
\hline \multicolumn{4}{|l|}{ Utilization of: } \\
\hline Acetate & - & + & + \\
\hline D-Glucose & - & + & + \\
\hline D-Ribose & - & + & + \\
\hline D-Fructose & - & + & + \\
\hline L-Arginine & - & + & + \\
\hline L-Aspartate & - & + & + \\
\hline L-Glutamate & - & + & + \\
\hline Sucrose & - & + & + \\
\hline Glycine & + & + & - \\
\hline Glycerol & - & + & + \\
\hline D-Mannitol & - & + & + \\
\hline myo-Inositol & - & + & + \\
\hline Salicin & - & + & + \\
\hline Sorbitol & - & + & + \\
\hline \multicolumn{4}{|l|}{ Fatty acids ( $\%$ of total) } \\
\hline $10: 0$ & $0 \cdot 2$ & $3 \cdot 5$ & ND \\
\hline $12: 0$ & $1 \cdot 7$ & $3 \cdot 1$ & $\mathrm{ND}$ \\
\hline $16: 0$ & $4 \cdot 2$ & $2 \cdot 9$ & $3 \cdot 04$ \\
\hline $18: 0$ & $4 \cdot 1$ & $1 \cdot 9$ & $1 \cdot 1$ \\
\hline $18: 1 \omega 7 c$ & $64 \cdot 1$ & $68 \cdot 8$ & $84 \cdot 6$ \\
\hline 11-Methyl $18: 1 \omega 7 c$ & $10 \cdot 6$ & $7 \cdot 5$ & ND \\
\hline $18: 3 \omega 6 c(6,9,12)$ & $3 \cdot 3$ & $\mathrm{ND}$ & ND \\
\hline 2-OH 16:0 & $3 \cdot 9$ & $\mathrm{ND}$ & ND \\
\hline 3-OH 10:0 & $2 \cdot 1$ & $1 \cdot 5$ & $1 \cdot 9$ \\
\hline 3-OH 12:0 & $1 \cdot 0$ & $5 \cdot 8$ & ND \\
\hline $3-\mathrm{OH} \mathrm{12:1}$ & ND & ND & $4 \cdot 0$ \\
\hline 19:0 cyclo & $\mathrm{ND}$ & $2 \cdot 3$ & ND \\
\hline ECL $11 \cdot 799$ & $1 \cdot 2$ & $\mathrm{ND}$ & $3 \cdot 6 \ddagger$ \\
\hline
\end{tabular}

${ }^{*}$ Data from Uchino et al. (1998).

$\dagger$ Data from Rüger \& Höfle (1992).

$\ddagger$ Reported as ECL $11 \cdot 798$.
CL-TA03 ${ }^{\mathrm{T}}$ to sea salts was determined using synthetic ZoBell broth (Bacto peptone, $5 \mathrm{~g}$; yeast extract, $1 \mathrm{~g}$; ferric citrate, $0 \cdot 1 \mathrm{~g}$; distilled water to $1 \mathrm{l}$ ) with various concentrations [0, $1,3,5,7,10,15,20$ and $25 \%$ (w/v)] of sea salts (Sigma). The ionic requirements of strain CL-TA0 $3^{\mathrm{T}}$ were determined after incubation for 21 days at $30^{\circ} \mathrm{C}$ using synthetic ZoBell agar with the following combinations of salts: (i) $3 \%(\mathrm{w} / \mathrm{v})$ $\mathrm{NaCl}$; (ii) $3 \%(\mathrm{w} / \mathrm{v}) \mathrm{NaCl}, 0 \cdot 6 \%(\mathrm{w} / \mathrm{v}) \mathrm{MgCl}_{2} \cdot 6 \mathrm{H}_{2} \mathrm{O}$ and $0 \cdot 3 \%$ (w/v) $\mathrm{MgSO}_{4} .7 \mathrm{H}_{2} \mathrm{O}$; (iii) $3 \%$ (w/v) NaCl, $0 \cdot 6 \%$ (w/v) $\mathrm{MgCl}_{2} \cdot 6 \mathrm{H}_{2} \mathrm{O}, 0.3 \%$ (w/v) $\mathrm{MgSO}_{4} .7 \mathrm{H}_{2} \mathrm{O}$ and $0.06 \%(\mathrm{w} / \mathrm{v})$ $\mathrm{KCl}$; (iv) $3 \%$ (w/v) NaCl, $0.6 \%$ (w/v) $\mathrm{MgCl}_{2} \cdot 6 \mathrm{H}_{2} \mathrm{O}, 0 \cdot 3 \%$ (w/v) $\mathrm{MgSO}_{4} .7 \mathrm{H}_{2} \mathrm{O}, 0.06 \%(\mathrm{w} / \mathrm{v}) \mathrm{KCl}$ and $0.2 \%(\mathrm{w} / \mathrm{v})$ $\mathrm{CaCl}_{2} \cdot 2 \mathrm{H}_{2} \mathrm{O}$. Strain CL-TA03 ${ }^{\mathrm{T}}$ was unable to grow on ZoBell agar with $\mathrm{Na}^{+}, \mathrm{Mg}^{2+}$ and $\mathrm{K}^{+}$, and was able to grow only on medium additionally supplemented with $\mathrm{Ca}^{2+}$. Catalase and oxidase activities were determined according to the protocols described by Smibert \& Krieg (1994) and gelatinase, amylase, DNase, nitrate reductase activities and degradation of Tween 80 were examined as described by Hansen \& Sørheim (1991). In addition, nitrate reduction, production of indole, arginine dihydrolase, urease, gelatinase, $\beta$-galactosidase, acid production from glucose and hydrolysis of aesculin were tested using the API 20NE kit (bioMérieux) according to the manufacturer's instructions, except that the cell suspension was prepared using artificial seawater $\left(\mathrm{NaCl}, 24 \mathrm{~g} ; \mathrm{MgCl}_{2}, 5 \cdot 1 \mathrm{~g} ; \mathrm{Na}_{2} \mathrm{SO}_{4}, 4 \mathrm{~g} ; \mathrm{CaCl}_{2}\right.$, $1.1 \mathrm{~g} ; \mathrm{KCl}, 0.7 \mathrm{~g} ; \mathrm{NaHCO}_{3}, 0.2 \mathrm{~g} ; \mathrm{KBr}, 0.1 \mathrm{~g} ; \mathrm{H}_{3} \mathrm{BO}_{3}$, $0.027 \mathrm{~g} ; \mathrm{SrCl}_{2}, 0.024 \mathrm{~g}$; NaF, 0.003 g; distilled water to $1 \mathrm{l}$; Lyman \& Fleming, 1940) as a suspension medium. Other enzyme activities were also assayed using the API ZYM kit (bioMérieux) and artificial seawater as a suspension medium. Carbon utilization was tested on basal agar medium supplemented with yeast extract $(\mathrm{NaCl}, 23.6 \mathrm{~g}$; $\mathrm{KCl}, 0 \cdot 64 \mathrm{~g}, \mathrm{MgCl}_{2} \cdot 6 \mathrm{H}_{2} \mathrm{O}, 4.53 \mathrm{~g} ; \mathrm{MgSO}_{4} .7 \mathrm{H}_{2} \mathrm{O}, 5 \cdot 94 \mathrm{~g}$; $\mathrm{CaCl}_{2} .2 \mathrm{H}_{2} \mathrm{O}, 1 \cdot 3 \mathrm{~g} ; \mathrm{NaNO}_{3}, 0.2 \mathrm{~g} ; \mathrm{NH}_{4} \mathrm{Cl}, 0 \cdot 2 \mathrm{~g} ;$ Bacto agar, $15 \mathrm{~g}$; yeast extract, $0.05 \mathrm{~g}$; distilled water to $1 \mathrm{l}$; Choi et al., 2006) containing $0 \cdot 2 \%$ of the carbon source. Incubation was prolonged for 1 month and growth was scored as positive when visible colonies were observed. Growth of CL-TA03 $3^{\mathrm{T}}$ was observed at temperatures of $15-35^{\circ} \mathrm{C}$, with optimum growth between 30 and $35^{\circ} \mathrm{C}$. Growth occurred from $\mathrm{pH} 6$ to 10 . Strain CL-TA03 ${ }^{\mathrm{T}}$ grew at sea salt concentrations of $3-7 \%$ and could degrade starch and gelatin and reduce nitrate to nitrite. CL-TA $03^{\mathrm{T}}$ was positive for cytochrome oxidase, catalase and alkaline phosphatase, but negative for valine arylamidase, $\beta$-galactosidase and $\alpha$-glucosidase (Table 1 ). The results of the other biochemical and physiological tests are given in Table 1 and in the species description.

Isoprenoid quinones were isolated according to Minnikin et al. (1984) and analysed by HPLC as described by Collins (1985). The major isoprenoid quinone in CL-TA03 ${ }^{\mathrm{T}}$ is UQ-10. The fatty acid methyl esters in whole cells were analysed by gas chromatography according to the instructions of the Microbial Identification System (MIDI) at the Korean Culture Center of Microorganisms in Seoul, Korea. The dominant fatty acid for $\mathrm{CL}^{-\mathrm{TA}} 03^{\mathrm{T}}$ was $18: 1 \omega 7 c$ 
$(64 \cdot 1 \%)$, which is a characteristic common to the Roseobacter clade, followed by 11-methyl $18: 1 \omega 7 c(10 \cdot 6 \%), 16: 0$ $(4 \cdot 2 \%)$ and $18: 0(4 \cdot 1 \%)$ (Table 1$)$.

In terms of phenotypic features, strain CL-TA $03^{\mathrm{T}}$ could be differentiated from the closely related genus Thalassobius by the absence of granules inside cells, the presence of weak amylase activity and the absence of growth on acetate, D-glucose, D-ribose, D-fructose, D-mannitol, myo-inositol, sorbitol, salicin, glycerol, L-arginine, L-aspartate, L-glutamate and sucrose as the sole carbon source. Furthermore, fatty acid profiles could distinguish CL-TA $03^{\mathrm{T}}$ from the two Thalassobius species (Table 1). The fatty acid profile of strain CL-TA $03^{\mathrm{T}}$ was different from that of T. mediterraneus mainly by the proportions of $18: 1 \omega 7 c$ and 11-methyl $18: 1 \omega 7 c$, and from that of $T$. gelatinovorus mainly by the proportions of minor fatty acids including $10: 0,19: 0$ cyclo, $18: 3 \omega 6 c(6,9,12)$ and 2-OH 16:0. Moreover, phylogenetic analysis of the $16 \mathrm{~S}$ rRNA gene sequence clearly showed that strain CL-TA $03^{\mathrm{T}}$ could not be classified as a member of any known genera in the Roseobacter clade. Therefore, phylogenetic analyses based on 16S rRNA gene sequences, fatty acid profile and phenotypic features indicated that strain CL-TA $03^{\mathrm{T}}$ should be classified as a novel genus and species, for which the name Shimia marina gen. nov., sp. nov. is proposed.

\section{Description of Shimia gen. nov.}

Shimia (Shi'mi.a. N.L. fem. n. Shimia named in honour of Dr Jae H. Shim, for his contributions to marine plankton ecology in Korea).

Cells are Gram-negative and rod-shaped. Growth is heterotrophic and strictly aerobic. Catalase- and oxidase-positive. Absence of granules inside cells. The predominant isoprenoid quinone is UQ-10. The dominant fatty acid is $18: 1 \omega 7 c$. Cells do not contain bacteriochlorophyll $a$. The genus is a member of the family Rhodobacteraceae. The type species is Shimia marina.

\section{Description of Shimia marina sp. nov.}

Shimia marina (ma.ri' na. L. fem. adj. marina of or belonging to the sea, marine).

Displays the following properties in addition to those given in the genus description. Cells are approximately $0 \cdot 3-$ $0.6 \mu \mathrm{m}$ wide and $0.8-3.6 \mu \mathrm{m}$ long. Cells are motile by several monopolar flagella. On MA medium, colonies are circular, entire, convex, opaque and colourless or beige. Grows at $15-35^{\circ} \mathrm{C}$ (optimum $30-35^{\circ} \mathrm{C}$ ) and at pH 6-10. Growth occurs at sea-salt concentrations of 3-7\% (w/v). No growth without sea salts in the medium. Amylase, gelatinase, nitrate reductase, DNase and Tween 80 hydrolysis activities are present. According to API 20NE tests, nitrate reductase, indole production, acid production from glucose, arginine dihydrolase, aesculin hydrolysis, gelatinase and urease activities are not detected. According to API ZYM tests, alkaline phosphatase and leucine arylamidase activities are present and esterase (C4), esterase lipase (C8) and acid phosphatase activities are weakly present, whereas lipase (C14), valine arylamidase, cystine arylamidase, trypsin, $\alpha$-chymotrypsin, naphthol-phosphohydrolase, $\alpha$-galactosidase, $\beta$-galactosidase, $\beta$-glucuronidase, $\alpha$-glucosidase, $\beta$-glucosidase, $N$-acetyl- $\beta$-glucosaminidase, $\alpha$-mannosidase and $\alpha$-fucosidase activities are absent. Major fatty acids are $18: 1 \omega 7 c, 11$-methyl $18: 1 \omega 7 c, 16: 0,18: 0,18: 3 \omega 6 c$ $(6,9,12)$ and $2-\mathrm{OH} 16: 0$. Growth occurs on acetone, $\alpha$-ketobutyric acid, citrate, ethanol, glycine, glycogen, L-leucine, L-lysine, L-ornithine, pyruvate, D-raffinose, succinate, tartrate and urea. No growth occurs on acetamide, L-ascorbate, benzoate, acetate, D-cellobiose, D-galactose, D-glucose, lactose, D-mannose, D-ribose, D-xylose, D-fructose, formic acid, glycerol, inulin, 2-propanol, L-arabinose, L-aspartate, L-arginine, L-glutamate, L-asparagine, L-proline, D-mannitol, maleic acid, myo-inositol, $\mathrm{N}$-acetylglucosamine, L-rhamnose, salicylate, salicin, sorbitol, sucrose, thiamine or D-trehalose. The DNA G + C content of the type strain is $57 \cdot 2 \mathrm{~mol} \%$.

The type strain is $\mathrm{CL}^{-\mathrm{TA} 03^{\mathrm{T}}}\left(=\mathrm{KCCM} 42117^{\mathrm{T}}=\mathrm{JCM}\right.$ $13038^{\mathrm{T}}$ ), isolated from a biofilm in a coastal fish farm in Korea.

\section{Acknowledgements}

This work was supported in part by the Special Grants Research Program in Fisheries (MOMAF) to B.C.C. (20000039) and by the BK21 project of the Korean Government.

\section{References}

Altschul, S. F., Gish, W., Miller, W., Myers, E. W. \& Lipman, D. J. (1990). Basic local alignment search tool. J Mol Biol 215, 403-410.

Arahal, D. R., Macián, M. C., Garay, E. \& Pujalte, M. J. (2005). Thalassobius mediterraneus gen. nov., sp. nov., and reclassification of Ruegeria gelatinovorans as Thalassobius gelatinovorus comb. nov. Int J Syst Evol Microbiol 55, 2371-2376.

Buchan, A., González, J. M. \& Moran, M. A. (2005). Overview of the marine Roseobacter lineage. Appl Environ Microbiol 71, 5665-5677.

Choi, D. H., Kim, Y.-G., Hwang, C. Y., Yi, H., Chun, J. \& Cho, B. C. (2006). Tenacibaculum litoreum sp. nov., isolated from tidal flat sediment. Int J Syst Evol Microbiol 56, 635-640.

Cole, J. R., Chai, B., Marsh, T. L. \& 8 other authors (2003). The Ribosomal Database Project (RDP-II): previewing a new autoaligner that allows regular updates and the new prokaryotic taxonomy. Nucleic Acids Res 31, 442-443.

Collins, M. D. (1985). Analysis of isoprenoid quinones. Methods Microbiol 18, 329-366.

Dang, H. \& Lovell, C. R. (2000). Bacterial primary colonization and early succession on surfaces in marine waters as determined by amplified rRNA gene restriction analysis and sequence analysis of 16S rRNA genes. Appl Environ Microbiol 66, 467-475.

Fitch, W. M. (1971). Toward defining the course of evolution: minimum change for a specific tree topology. Syst Zool 20, 406-416.

Giovannoni, S. J. \& Rappé, M. S. (2000). Evolution, diversity and molecular ecology of marine prokaryotes. In Microbial Ecology of the Oceans, pp. 47-84. Edited by D. L. Kirchman. New York: Wiley. 
Hansen, G. H. \& Sørheim, R. (1991). Improved method for phenotypical characterization of marine bacteria. J Microbiol Methods 13, 231-241.

Jeon, Y.-S., Chung, H., Park, S., Hur, I., Lee, J.-H. \& Chun, J. (2005). jPHYDIT: a JAVA-based integrated environment for molecular phylogeny of ribosomal RNA sequences. Bioinformatics 21, 3171-3173.

Jukes, T. H. \& Cantor, C. R. (1969). Evolution of protein molecules. In Mammalian Protein Metabolism, pp. 21-132. Edited by H. N. Munro. New York: Academic Press.

Kumar, S., Tamura, K. \& Nei, M. (2004). MEGA3: integrated software for molecular evolutionary genetics analysis and sequence alignment. Brief Bioinform 5, 150-163.

Lane, D. J. (1991). 16S/23S rRNA sequencing. In Nucleic Acid Techniques in Bacterial Systematics, pp. 115-175. Edited by E. Stackebrandt \& M. Goodfellow. Chichester: Wiley.

Lyman, J. \& Fleming, R. H. (1940). Composition of sea water. J Mar Res 3, 134-146.

Marmur, J. (1961). A procedure for the isolation of deoxyribonucleic acid from microorganisms. J Mol Biol 3, 208-218.

Mesbah, M., Premachandran, U. \& Whitman, W. B. (1989). Precise measurement of the $\mathrm{G}+\mathrm{C}$ content of deoxyribonucleic acid by high-performance liquid chromatography. Int J Syst Bacteriol 39, 159-167.

Minnikin, D. E., O’Donnell, A. G., Goodfellow, M., Alderson, G. Athalye, M., Schaal, K. \& Parlett, J. H. (1984). An integrated procedure for the extraction of bacterial isoprenoid quinones and polar lipids. J Microbiol Methods 2, 233-241.

Ostle, A. G. \& Holt, J. G. (1982). Nile blue A as a fluorescent stain for poly- $\beta$-hydroxybutyrate. Appl Environ Microbiol 44, 238-241.

Rüger, H.-J. \& Höfle, M. G. (1992). Marine star-shaped-aggregateforming bacteria: Agrobacterium atlanticum sp. nov.; Agrobacterium meteori sp. nov.; Agrobacterium ferrugineum sp. nov., nom. rev.; Agrobacterium gelatinovorum sp. nov., nom. rev.; and Agrobacterium stellulatum sp. nov., nom. rev. Int J Syst Bacteriol 42, 133-143.

Saitou, N. \& Nei, M. (1987). The neighbor-joining method: a new method for reconstructing phylogenetic trees. Mol Biol Evol 4, 406-425.

Selje, N., Simon, M. \& Brinkhoff, T. (2004). A newly discovered Roseobacter cluster in temperate and polar oceans. Nature 427, $445-448$.

Smibert, R. M. \& Krieg, N. R. (1994). Phenotypic characterization. In Methods for General and Molecular Bacteriology, pp. 607-654. Edited by P. Gerhardt, R. G. E. Murray, W. A. Wood \& N. R. Krieg. Washington, DC: American Society for Microbiology.

Uchino, Y., Hirata, A., Yokota, A. \& Sugiyama, J. (1998). Reclassification of marine Agrobacterium species: proposals of Stappia stellulata gen. nov., comb. nov., Stappia aggregata sp. nov., nom. rev., Ruegeria atlantica gen. nov., comb. nov., Ruegeria gelatinovora comb. nov., Ruegeria algicola comb. nov., and Ahrensia kieliense gen. nov., sp. nov., nom. rev. J Gen Appl Microbiol 44, 201-210. 